\title{
An environmental database and temporal and spatial distribution of Chinese paleoanthropological sites
}

\author{
WU ChunLin ${ }^{1,2}$, ZHANG Yan ${ }^{1}$, LI Qin ${ }^{1}$, GUO ZhengTang ${ }^{*}$ \& GAO Xing ${ }^{3}$ \\ ${ }^{1}$ Key Laboratory of Cenozoic Geology and Environment, Institute of Geology and Geophysics, Chinese Academy of Sciences, Beijing 100029, \\ China; \\ ${ }^{2}$ Graduate University of Chinese Academy of Sciences, Beijing 100049, China; \\ ${ }^{3}$ Laboratory of Human Evolution, Institute of Vertebrate Paleontology and Paleoanthropology, Chinese Academy of Sciences, Beijing 100044, \\ China
}

Received June 16, 2011; accepted July 6, 2011; published online August 30, 2011

\begin{abstract}
A comprehensive database of paleoenvironmental settings for paleoanthropological sites provides a useful tool to explore the link between human evolution and paleoenvironmental changes. A preliminary GIS-based environmental database for paleoanthropological sites in China (EDPC) was constructed based on data collected from published literature. The database currently contains 1114 paleoanthropological sites. It will be available for online access following the establishment of relevant rules, and after improvement and further development through regular and sustained updates by internal and external users. Preliminary analyses using the GIS system yielded new evidence regarding human-environmental relationships.
\end{abstract}

paleoanthropological sites, paleoenvironments, database, quaternary

Citation: Wu C L, Zhang Y, Li Q, et al. An environmental database and temporal and spatial distribution of Chinese paleoanthropological sites. Chinese Sci Bull, 2011, 56: 3281-3283, doi: 10.1007/s11434-011-4669-7

Exploring the link between human evolution and paleoenvironmental change is a hot topic in Quaternary Geology and Paleoanthropology [1,2]. A comprehensive database of paleoenvironments for paleoanthropological sites can provide valuable information for the advancement of this field. Efforts to compile this database were initiated in 2007 under support of the Specific Basic Research Program of the Ministry of Science and Technology of China. Finally, a preliminary GIS-based environmental database for paleoanthropological sites of China (EDPC) has been compiled at the Institute of Geology and Geophysics, Chinese Academy of Science (IGGCAS).

The structure and information for the database are shown in Figure 1. The database now contains 1114 paleoanthropological sites from China (Figure 2(a)). The compiled data mainly were obtained from literature published between 1920 and 2010, and include more than 800 representative

*Corresponding author (email: ztguo@mail.iggcas.ac.cn) journal papers, 38 books and 26 theses. The collected information has been examined, classified and linked to the source literature. Emphasis was given to geographical information, chronology and indicators of paleoenvironmental conditions. Geographical data of the paleoanthropological sites are linked with a digital geographic base map [3] and the global SRTM digital elevation data (http://srtm.csi.cgiar. org/Index.asp).

Among the 1114 sites examined, 106 contain human fossils, while the others are mostly identified by paleolithic tools. In total, 152 sites contain isotope or paleomagnetic chronology data. A total of 69 sites were dated by mammalian fossil assemblages. The chronologies of 828 sites were estimated through stratigraphy correlations and 54 were estimated based on characteristics of associated artifacts. A total of 11 sites were dated by comprehensive analysis of stratigraphy correlations and mammalian fossil assemblages.

Indicators with explicit environmental significance (e.g. pollens, animal fossils) were available for 94 sites. Analytical 


\begin{tabular}{|c|c|c|c|c|c|}
\hline \multicolumn{6}{|c|}{ Site name } \\
\hline$\downarrow$ & $\downarrow$ & $\downarrow$ & 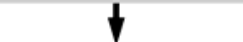 & $\downarrow$ & $\downarrow$ \\
\hline $\begin{array}{c}\text { Geography } \\
\text { information }\end{array}$ & & & & & \\
\hline $\begin{array}{l}\text {-Regionalism } \\
\text {-Schematic map } \\
\text {-Geographic } \\
\text { coordinates } \\
\text {-Hypsography } \\
\text {-Elevation }\end{array}$ & $\begin{array}{l}\text { - Geological age } \\
\text {-Dating method } \\
\text {-Dating material } \\
\text { - Lower age limit } \\
\text { - Upper age limit }\end{array}$ & $\begin{array}{l}\text {-Archaeological } \\
\text { period } \\
\text { - Burial pattern } \\
\text {-Purpose of site } \\
\text { - Fire-use remains } \\
\text { - Classification } \\
\text { of cultural relics }\end{array}$ & $\begin{array}{l}\text {-Landform } \\
\text {-Landform history } \\
\text { - Lithology description } \\
\text { - Lithology } \\
\text { of cultural layer } \\
\text {-Sedimentary facies } \\
\text { of cultural layer }\end{array}$ & $\begin{array}{l}\text {-Type of } \\
\text { environmemtal } \\
\text { indicator } \\
\text {-Paleovegetation } \\
\text { interpretation of } \\
\text { cultural layer } \\
\text {-Paleoclimate } \\
\text { interpretation of } \\
\text { cultural layer }\end{array}$ & $\begin{array}{l}\text { - Time of excavation } \\
\text {-Area of excavation } \\
\text { - Thickness of } \\
\text { cultural layer } \\
\text { - References }\end{array}$ \\
\hline
\end{tabular}

Figure 1 Schematic structure of the environmental database for paleoanthropological sites of China.

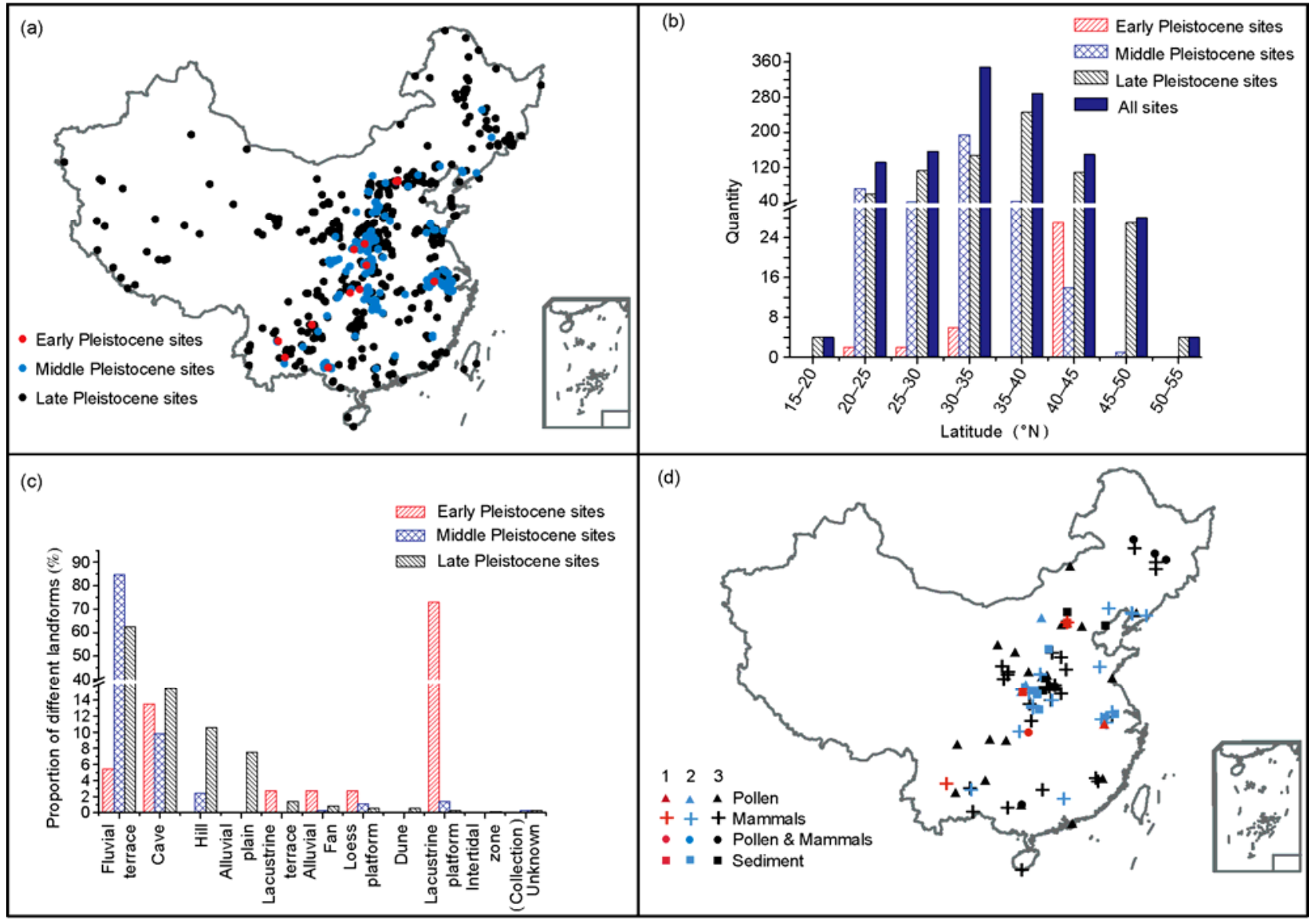

Figure 2 Distribution of the sites in EDPC. (a) Spatial distribution of paleoanthropological sites of different periods; (b) latitudinal distribution of the sites; (c) geomorphic distribution of the sites; (d) distribution of the sites with paleoenvironmental data. Columns 1, 2, 3 represent the early, middle and late Pleistocene sites, respectively.

data with high-resolution were rare. However, quality time series of paleoenvironments were available for some regions, such as the Loess Plateau in northern China [4]. Paleoenvironmental results from the loess-soil sequences provided useful background information for the nearby paleoanthropological sites, particularly when the chronology or stratigraphy of the sites were well constrained.

The reported database allows the exploration of spatial and temporal distributions of the sites using GIS techniques. This provides new evidence with regards to the relationship 
of human activity and environmental conditions.

Early and mid-Pleistocene sites were mostly distributed in the eastern monsoon region, with a peak concentration between $30^{\circ}$ and $35^{\circ} \mathrm{N}$ (Figure 2(a), (b)). These peaks indicate suitability of the mid-latitude monsoon climate for Paleolithic humans. Only late Pleistocene sites were reported from the Tibetan Plateau and the Xinjiang region. The number of sites in the tropical zone between $0^{\circ}-20^{\circ} \mathrm{N}$ represents a small proportion of the total number of sites. This is probably due to the lack of open landscapes under forest conditions. Lack of research and preservation conditions of remains might also be responsible for the dearth of data in this zone.

In terms of geomorphology, most of the early and midPleistocene sites were associated with fluvial/lacustrine terraces and cave environments, while the site number tends to expand in the late Pleistocene towards hilly and highland zones (Figure 2(c)). This evidence suggests a stronger reliance of early and mid-Pleistocene human activities around water sources and a decrease of this reliance in the late Pleistocene and/or higher capacity of adaptation to topography. These relationships are attributable to various causes, which will need further study.

Despite the lack of accurate chronology data for most sites, the available environmental indicators clearly show that the paleoanthropological sites of the early and mid-
Pleistocene north to $40^{\circ} \mathrm{N}$ mostly were associated with interglacial-type environments. Sites with glacial environmental indicators only emerged in the late Pleistocene (Figure 2(d)) in northern and northwestern China, a time with even globally cooler conditions [5]. These trends tend to suggest that early and mid-Pleistocene humans in northern China essentially were not well adapted to the glacial environments. Conversely, human adaptation to a wide range of environmental conditions would have been facilitated by a variety of factors, including greater intellectual knowledge and capacity, an increase in population size and technological advances in the late Pleistocene.

This work was supported by the Specific Basic Research Program of the Ministry of Science and Technology of China (2007FY110200).

1 Liu T S, Ding Z L. Quat Sci, 1999, 19: 289-298

2 Dennell R W, Martinón-Torres M, Bermúdez de Castro J M. Quat Sci Rev, 2010, doi: 10.1016/j.quascirev.2009.11.027

3 Tian Q, Li J, Huang F H, et al. Resources and Environment Database of China (1:4000000). Beijing: State Key Laboratory of Resources and Environmental Information System, Institute of Geographic Sciences and Natural Resources Research, Chinese Academy of Sciences, 1996

4 Liu T S. In: Xu Q Q, Xie F, Wang J, eds. International Symposium for the Celebration of Chinese Academician Jia Lanpo's 90th Birthday-New Advance of Archaeology in Prehistory (in Chinese). Beijing: Science Press, 1999. 52-62

5 Zachos J, Pagani M, Sloan L, et al. Science, 2001, 292: 686-693

Open Access This article is distributed under the terms of the Creative Commons Attribution License which permits any use, distribution, and reproduction in any medium, provided the original author(s) and source are credited. 